\author{
JACEK Z. KUBIAK ${ }^{1,2}$ \\ ${ }^{1}$ Zakład Embriologii Doświadczalnej \\ Instytut Genetyki i Biotechnologii Zwierzat PAN \\ Postępu 36A, Jastrzębiec, 05-552 Magdalenka \\ ${ }^{2}$ UnivRennes, UMR 6290, CNRS \\ Institute of Genetics and Development of Rennes \\ Faculty of Medicine \\ Rennes, France \\ E-mail: j.kubiak@igbzpan.pl \\ jacek.kubiak@univ-rennes1.fr
}

\title{
COVID-19 WE FRANCJI
}

\section{WSTEP}

Pandemia COVID-19 jest niezwykłym wydarzeniem w nowoczesnych dziejach ludzkości. Zakres i siła $z$ jaka wirus SARS-CoV-2 wywołujący COVID-19 zaatakował ludzkość jest bez precedensu. Głównym powodem tak szybkiego rozprzestrzeniania się choroby na całym świecie była jej szczególna natura, polegajaca na wywoływaniu bardzo zróżnicowanego przebiegu klinicznego: od zakażenia bezobjawowego, poprzez łagodna formę podobną do przeziębienia, aż po ciężkie, smiertelne w skutkach zapalenie płuc. Około pięciodniowy okres wylęgania się choroby, równocześnie $z$ pełnymi możliwościami zakażania $\mathrm{i}$ w połaczeniu $\mathrm{z}$ obecnymi szansami szybkiego przemieszczania się samolotami $z$ jednego końca świata na drugi spowodowały, że choroba rozniosła się błyskawicznie po całej kuli ziemskiej. Jednak każdy kraj lub większy obszar objęty pandemia miał swoja własna specyfikę przebiegu rozwijania się choroby. W tym artykule opiszę przebieg pandemii COVID-19 we Francji.

\section{POCZAॄTEK PANDEMII WE FRANCJI}

Pierwsze oficjalnie stwierdzone trzy przypadki COVID-19 we Francji, a zarazem w Europie, zanotowano 24 stycznia 2020 r. w
Bordeaux i w Paryżu. Do 29 stycznia było już 5 przypadków zidentyfikowanych $\mathrm{w}$ obu miastach francuskich. Pierwsi francuscy pacjenci to trzech mężczyzn (w wieku 31, 48 i 80 lat) i dwie kobiety (w wieku 30 i 46 lat). Wszyscy byli pochodzenia chińskiego i przybyli do Francji $z$ Chin w połowie stycznia. Opis tych przypadków ukazał się w marcu 2020 online (ostateczna wersja artykułu w czerwcu 2020 r.) w czasopiśmie naukowym Lancet Infectious Diseases (LESCURE i współaut. 2020). Pomimo małej liczby pacjentów opisano trzy różne typy ewolucji klinicznego przebiegu choroby: (i) dwie kobiety bez objawów choroby, zdiagnozowane w ciagu jednego dnia od wystapienia objawów, $z$ wysokimi mianami SARS-CoV-2 w nosogardzieli w ciagu pierwszych 24 godzin od zachorowania i $\mathrm{z}$ wykryciem wirusowego RNA w kale, (ii) dwóch młodych mężczyzn $z$ dwuetapowym postępem choroby, w tym $\mathrm{z}$ wtórnym pogorszeniem około 10 dni po wystapieniu pierwszych symptomów pomimo zmniejszajacego się miana wirusa w próbkach pobranych z nosogardzieli, (iii) 80-letni mężczyzna z szybka ewolucja w kierunku niewydolności wielonarządowej i utrzymującym się wysokim mianem wirusa $\mathrm{w}$ dolnych i górnych drogach oddechowych, $z$ ogólnoustrojowym rozprzestrzenianiem się wirusa i $z$ wykryciem wirusa w osoczu. Ten pacjent zmarł $\mathrm{w}$ 
14. dniu choroby (14.02.2020), podczas gdy wszyscy pozostali wyzdrowieli i zostali wypisani ze szpitali do 19 lutego 2020 r. Opis tych przypadków bardzo przypominał to, co znano już $z$ Chin, gdzie $w$ momencie wykrycia pierwszych przypadków COVID-19 w Europie, już oficjalnie zanotowano śmierć 41 pacjentów. Po pierwsze potwierdzono, że tak jak w Chinach, pacjenci reaguja bardzo różnie na infekcję SARS-CoV-2: od braku objawów, przez stosunkowo lagodny przebieg choroby, aż do poważnego, zakończonego zgonem. Wśród tych pierwszych francuskich pacjentów zauważono również, co później miało potwierdzić się statystycznie, że kobiety radza sobie lepiej $z$ infekcja SARS-VCoV-2 niż mężczyźni, a szczególnie wrażliwi moga być pacjenci w starszym wieku.

\section{PRZEBIEG PANDEMII WE FRANCJI}

Od tej pory przyrost wykrywanych przypadków infekcji i wzrost liczby przyjęć do szpitali zaczał następować w błyskawicznym tempie. W okresie od 1 marca do 30 kwietnia 2020 r. dobowa nadwyżka śmiertelności we Francji wzrosła o $33 \%$ w stosunku do wartości średnich $z$ lat 2000-2019. Dziennik Le Monde z 27 kwietnia 2020 r. w artykule „Koronawirus: bardzo wyraźny szczyt śmiertelności we Francji odnotowany $\mathrm{w}$ marcu i kwietniu" donosił, że każdego dnia rejestrowano średnio 2120 zgonów, wobec średniej liczby 1590 zgonów w tym samym okresie roku w latach 2000-2019 (FERRER i BRETEAU 2020). Pandemia we Francji była już faktem i nikt nie potrafił $\mathrm{w}$ pełni ocenić, jakie będa jej skutki dla kraju, zarówno sanitarne, jak i gospodarcze.

W połowie marca 2020 r. władze sanitarne Francji wprowadziły obowiązek izolacji domowej, (ang. lock-out; franc. confinement). Obostrzenia trwały do połowy maja lub połowy lipca 2020 r., w zależności od regionu Francji (GOPINATH 2020). Następnie, wraz z dalszym wzrostem liczby zakażeń w okresie od listopada 2020 r. do czerwca 2021 r., ogłaszane były jeszcze dwa lock-outy oraz została narzucona godzina policyjna. To ostanie obostrzenie, niezastosowane w Polsce, miało ograniczyć aktywność Francuzów tak, aby chronić ich przed zakażeniem, szczególnie podczas okresów luzowania obostrzeń.

W 2021 r. pandemia COVID-19 we Francji przybrała inny nieco przebieg wraz $z$ pojawieniem się bardziej zaraźliwych wariantów wirusa. 7 stycznia $2021 \mathrm{r}$. potwierdzono 19 przypadków zakażenia wariantem alfa, znanym wówczas jako wariant brytyjski. W ciagu kilku następnych tygodni co czwarta infekcja we Francji dotyczyła już warian- tu brytyjskiego (Dane Rządu Francuskiego 2020, https://www.data.gouv.fr/fr/reuses/ levolution-du-variant-britannique-en-france/).

Równolegle $z$ pojawieniem się wariantu brytyjskiego SARS-CoV-2, od początku 2021 r., organizowano kampanię szczepień. Tempo szczepień było jednak powolne. Władze francuskie chciały uniknąc zbyt agresywnej propagandy, aby nie zachęcać do działania antyszczepionkowców. Do dnia 28 lutego 2021 r. ponad 3 miliony Francuzów otrzymało pierwszą dawkę szczepionki, a 1,5 miliona również druga dawkę. $Z$ podanymi wówczas 6,6 dawkami na 100 mieszkańców Francja była jednak daleko w tyle za Izraelem, Wielką Brytanią czy Stanami Zjednoczonymi i na poziomie nieco niższym niż Niemcy czy Włochy. Dopiero w ciagu pierwszych sześciu miesięcy 2021 r. zaszczepiona została połowa populacji.

Pod koniec lipca 2021 r. ogłoszono tzw. czwarta fale pandemii COVID-19, która zależała już wyraźnie od wariantu delta (indyjskiego) SARS-CoV-2. Wprowadzono wówczas tzw. paszport sanitarny czy covidowy, dla osób zaszczepionych i ozdrowieńców. Początkowo obowiazywal on w kinach, teatrach, muzeach, parkach rozrywki, kościołach i innych miejscach kultu $\mathrm{i}$ w szpitalach. Następnie, od poczatku sierpnia 2021 r., rozszerzono obowiazek posiadania paszportu covidowego o bary, restauracje, pociagi i samoloty. Ten krok bardzo przyspieszył proces szczepień, gdyż Francuzi zrozumieli, że bez tego dokumentu nie będa mogli swobodnie korzystać $z$ barów, kawiarni i restauracji, a więc nie będa mogli prowadzić normalnego życia. W ciagu kilku tygodni liczba zaszczepionych przekroczyła 60\% populacji Francji, a czwarta fala pandemii zaczęła powoli opadać (RAulin 2021).

Według stanu na 9 lipca 2021 r. Francja, która odnotowała nowy wzrost skażenia wraz $z$ pojawieniem się wariantu delta, miała całkowita liczbę 5803687 formalnie zidentyfikowanych przypadków, a łączna liczba zgonów wynosiła 111302 . Znane, nie tylko we Francji, osoby publiczne, które zmarły w wyniku pandemii COVID-19 to m.in.: księżniczka Marie-Thérèse de Bourbon-Parme, zmarła 26 marca 2020 r. w wieku 86 lat, polityk Patrick Devedjian zmarł 29 marca 2020 r. w wieku 75 lat, kameruński jazzman, saksofonista i wokalista Manu Dibango zmarł 24 marca 2020 roku w wieku 86 lat, byly prezydent Republiki Francuskiej, Valéry Giscard d'Estaing zmarł 2 grudnia 2020 r. w wieku 94 lat, reżyser, aktor i scenarzysta, Robert Hossein, zmarł 31 grudnia 2020 r. w wieku 93 lat, dziennikarz i eseista, Jean-Louis Servan-Schreiber, zmar1 28 listopada 2020 r. w wieku 83 lat 
(Wikipedia Francuska, https://fr.wikipedia. org/wiki/Liste_de_personnalit\%C3\%A9s_mortes_de_la_Covid-19).

\section{ŻYCIE CODZIENNE FRANCUZÓW W CZASIE PANDEMII COVID-19}

Od 17 marca 2020 r. Francuzi zostali skazani na życie w izolacji domowej, co ogłosił w orędziu telewizyjnym prezydent Emmanuel Macron (MACRON 2020). Francuzi, pomimo legend na ich temat, nie okazali się mniej subordynowani lub bardziej krnąbrni niż inne europejskie narody i zastosowali się do nowych zarządzeń i ograniczeń. Pierwsze, minimalne efekty izolacji domowej na przebieg pandemii można było zobaczyć i zmierzyć dopiero po dwóch tygodniach ze względu na maksymalny czas wylęgania się choroby. Władze sanitarne od samego poczatku pandemii nie ukrywały przed Francuzami, że podaja do wiadomości liczby, które nie odzwierciedlają rzeczywistości. Albowiem to, co często bierze się za liczbę chorych, w rzeczywistości jest liczba przypadków wykrytych przy pomocy testu PCR. Ponieważ testowano tylko mały wycinek populacji, czyli osoby, które wykazywały objawy zbliżone do COVID-19, to rzeczywista liczba chorych, a tym bardziej bezobjawowych zakażonych nosicieli wirusa, była o wiele wyższa od liczb podawanych w statystykach. Dlatego władze sanitarne zawsze podkreślały, że dokładne dane dotycza wyłącznie osób hospitalizowanych, przebywajacych na oddziałach intensywnej terapii i ozdrowieńców opuszczających szpitale.

Pomimo tego jasnego przekazu bardzo wielu Francuzów sądziło, że nie mówi się im całej prawdy. Ludzie nie byli bowiem przyzwyczajeni do uważnego słuchania komunikatów, a tym bardziej do ich pełnego rozumienia i przyswojenia. Dlatego szybko zaczęły krążyć w internecie informacje o ludziach masowo umierajacych w domach i nie ujętych w statystykach. Oczywiście takie informacje były od razu odbierane jako dowód na zmowę milczenia wokół choroby. Taki trend oczywiście pojawił się wówczas na całym świecie i nie był tylko specjalnością francuska.

Szczególnej krytyki ze strony Francuzów doczekała się decyzja prezydenta Macrona o przeprowadzeniu pierwszej tury wyborów lokalnych 15 marca 2020 r. (DoNADA 2020). W wyborach tych frekwencja była niezwykle niska jak na Francję, ponieważ wzięło w nich udział zaledwie $44 \%$ uprawnionych do głosowania. Pod wpływem krytyki prezydent bardzo szybko wycofał się $z$ pomysłu przeprowadzenia $\mathrm{w}$ trakcie obostrzeń pandemicznych drugiej tury wyborów, które przeprowadzono w późniejszym terminie.
Ważnym wydarzeniem dla początków pandemii było zakażenie około 800 uczestników spotkania religijnego, które miało miejsce od 17 do 24 lutego 2020 r. w Miluzie na wschodzie Francji. Od tej pory wschodnie rejony kraju (Alzacja, Szampania, Ardeny i Lotaryngia) były najbardziej dotknięte epidemia COVID-19. Tam też notowano najwięcej przypadków śmiertelnych i najbardziej przepełnione były szpitale. To wydarzenie i jego skutki pokazały Francuzom, jak niebezpieczne sa masowe imprezy w zamkniętych pomieszczeniach w okresie pandemii.

Francuska służba zdrowia borykała się $z$ licznymi problemami zwiazanymi $z$ masowym napływem pacjentów. Dodatkowo sytuację zaogniła, wprowadzana na krótko przed początkiem pandemii, reforma służby zdrowia, która ograniczyła liczbę łóżek szpitalnych, szczególnie na oddziałach zakaźnych. Studenci 4. i 5. roku medycyny i położnictwa dostali przydziały do poszczególnych szpitali, gdzie mieli podjacc pracę w przypadku ich przepełnienia lub w razie braku wystarczajacej liczby lekarzy i reszty personelu szpitalnego. Oczywiście to właśnie personel medyczny pracujacy przy chorych na COVID-19 sam był najbardziej narażony na zakażenie wirusem SARS-CoV-2. Bardzo wielu lekarzy i pielęgniarek pracowało pomimo groźby zakażenia, stosując jedynie maseczki i zalecane środki higieny.

\section{AFERA PROFESORA RAOULTA}

Bardzo duży wpływ na przebieg pandemii we Francji miała informacja o rzekomym antywirusowym działaniu leku o nazwie hydroksychlorochina. Już w trakcie epidemii w Wuhan Chińczycy donosili, że lek ten może leczyć COVID-19, chociaż były to jedynie obserwacje oparte na wynikach badań laboratoryjnych pokazujacych, że hydroksychlorochina ogranicza replikację SARS-CoV-2 w komórkach ludzkich hodowanych in vitro $\mathrm{w}$ laboratorium (WANG i współaut 2020). We Francji informację o takim działaniu hydroksychlorochiny rozpowszechnił lekarz z Marsylii, prof. Didier Raoult. Oczywiście Francuzi rzucili się od razu do aptek, by zdobyć ten rzekomo cudowny lek. Szpital w Marsylii, w którym przyjmował prof. Raoult, był wręcz oblężony przez pacjentów szukajacych $\mathrm{u}$ niego ratunku.

Didier Raoult podawał pacjentom zarażonym SARS-CoV-19 hydroksychlorochinę i antybiotyk azytromycynę (GAUTRET i współaut. 2020). Hydroksychlorochina jest lekarstwem o nazwie handlowej Plaquenil, stosowanym w leczeniu malarii, chorób na tle zapalnym (np. reumatycznych) i o działaniu przeciwbólowym. Działanie hydroksychlo- 
rochiny może przywracać tkankom $z$ obniżonym stężeniem tlenu (w stanie hipoksji) normalny stan utlenienia (normoksję) - stąd pewien zwiazek $\mathrm{z}$ COVID-19, kiedy u pacjenta dochodzi do niedotlenienia organizmu ze względu na zapalenie płuc. Azytromycyna zaś, jako antybiotyk, ma działanie antybakteryjne. Jej stosowanie mogło ewentualnie zabezpieczać pacjentów przed dodatkowymi zakażeniami bakteryjnymi, ale $\mathrm{w}$ żaden sposób nie mogło przyczynić się do bezpośredniego zwalczania koronawirusa. Jednak to właśnie zestaw tych dwóch leków według profesora Raoulta miał działać leczniczo w przypadkach COVID-19, i według jego przepisu oba leki miały być podawane chorym na samym poczatku choroby. Kontrolowane, randomizowane badania kliniczne obaliły jednak po jakimś czasie rewelacje Raoulta (TANG i współaut. 2021). Zarówno WHO, jak i francuskie władze sanitarne zakazały w końcu stosowania hydroksychlorochiny i azytromycyny w leczeniu COVID-19 jako terapii nieskutecznej, a wręcz szkodliwej, gdyż groziła poważnymi skutkami ubocznymi, szczególnie pacjentom $z$ wadami serca.

Jednak do tego czasu media, a szczególnie internet, prasa i telewizja spopularyzowały poglady Roulta we Francji na niespotykana skalę. Ten zaś okazał się samorodnym talentem medialnymi i po prostu uwiódł bardzo wielu Francuzów swoim krasomówstwem i tupetem. Lekarze, naukowcy, ale także politycy i zwykli ludzie podzielili się mniej więcej pół na pół w ocenie skuteczności terapii profesora Raoulta, choć nie mieli pojęcia o tym, jak ona działa w rzeczywistości. Odbywały się debaty telewizyjne na ten temat, a prezydent Macron udał się do Marsylii i odbył transmitowaną przez telewizję dyskusję $z$ Raoultem.

Co gorsza, Raoult twierdził, iż stosowanie hydroksychlorochiny w COVID-19 jest bojkotowane przez wielkie firmy farmaceutyczne, ponieważ jest to lek bardzo tani, a te przecież chca zbić majątek na nowych i bardzo drogich lekach. Takie oświadczenia medycznej sławy z Marsylii bardzo odpowiadały wyznawcom teorii spiskowych. Didier Raoult stał się więc szybko ich guru, i co najgorsze, nie robił nic, by takiemu obrotowi wydarzeń zapobiec. W pewnym momencie pandemii Raoult zaczał również przestrzegać, że spory odsetek osób zaszczepionych nie wytwarza przeciwciał przeciwko SARS-CoV-2 lub wytwarza ich za mało, aby - jak twierdził - zapewnić należyta ochronę przed COVID-19. Te rewelacje utwierdzały tylko antyszczepionkowców, że szczepionki sa nie tylko bezużyteczne, ale i szkodliwe. Trzeba dodać, że liczba przeciwciał nie jest jedyna miara jakości szczepionek. Szczepionki wywołuja bowiem również tzw. pamięć immunologiczną, która przyspiesza działanie układu odpornościowego w momencie infekcji, niezależnie od liczby przeciwciał znajdujących się we krwi pacjenta.

Kiedy specjaliści od wyszukiwania oszustw naukowych wzięli pod lupę publikacje naukowe Didier Raoulta dotyczace COVID-19 i hydroksychlorochiny, okazało się, że wiele $z$ tych doniesien jest bardzo wątpliwej jakości lub sa po prostu oszustwami naukowymi. Raoult oczywiście procesuje się ze swoimi oskarżycielami, ale na szczęście został już przynajmniej odwołany z funkcji dyrektora instytutu i przeszedł na emeryturę. Jego działania medialne podczas pandemii narobiły jednak we Francji bardzo wiele złego oraz wzmocniły głosy antyszczepionkowców i wyznawców wszelkich teorii spiskowych.

Streszczenie

Francja była jednym $z$ tych krajów europejskich, w których pandemia COVID-19 rozpoczęła się na samym poczatku 2020 r. To tu zidentyfikowano pierwszego pacjenta $z$ COVID-19 w Europie. W artykule opisuje subiektywne kalendarium wydarzeń związanych $z$ przebiegiem pandemii $\mathrm{w}$ tym kraju. Przedstawiam pewne wybrane zjawiska i etapy pandemii COVID-19 we Francji, które moga mieć znaczenie dla oceny, czy walka $z$ ta plaga była prowadzona dobrze czy źle. Ostateczne oceny będzie wystawiać historia.

\section{LITERATURA}

DONADA E., 2020. Le conseil scientifique avaitil validé la tenue des élections municipales? Libération, 15 mars 2020.

FERRER M., BRETEAU P., 2020. Coronavirus : un pic très net de mortalité en France enregistré en mars et auril. Le Monde, 27 avril 2020

GAUTRET P., LAGIER J.-C, PAROLA P. i współaut., 2020. Hydroxychloroquine and azithromycin as a treatment of COVID-19: results of an open-label non-randomized clinical trial. Int. J Antimicrob. Agents 56, doi: 10.1016/j.ijantimicag.2020.105949.

GOPINATH G., 2020. Le Grand confinement: pire récession économique depuis la Grande dépression. https://www.imf.org/fr/News/Articles / 2020/04/14/blog-weo-the-great-lockdown-worst-economic-downturn-since-thegreat-depression.

LESCURE F.-X., BOUADMA L., NGUYen D. i współaut., 2020. Clinical and virological data of the first cases of COVID-19 in Europe: a case series. Lancet Infect. Dis. 20, 697-706.

MACRON E., 2020. Discours du 16 mars 2020, https: / / www.youtube.com/watch?v=mhklV9uOvTQ

RAULIN N., 2021. Covid : comment la France a at teint son objectif de 50000000 de primo-vaccinés. Libération, $\square 15$ septembre 2021.

TANG W., KhaliLi L., GiLes J. i współaut., 2021. The rise and fall of hydroxychloroquine with the COVID-19 pandemic: Narrative review of selected data. Rheumatol. Ther. 8, 681-691.

WANG M., CAO R., Zhang L., YANG X., LIU J., XU M., 2020. Remdesivir and chloroquine effectively inhibit the recently emerged novel coronavirus (2019-nCoV) in vitro. Cell Res. 30, 269-271. 
Kosmos Vol. 70, 3, 469-473, 2021

JACEK Z. KUBIAK ${ }^{1,2}$

${ }^{1}$ Department of Experimental Embryology, Institute of Genetics and Animal Biotechnology PAS, 36A Posteppu Str., Jastrzębiec, 05-552 Magdalenka, ${ }^{2}$ UnivRennes, UMR 6290, CNRS, Institute of Genetics and Development of Rennes, Faculty of Medicine, Rennes, France, E-mail: j.kubiak@igbzpan.pl, jacek.kubiak@univ-rennes1.fr

\section{COVID-19 IN FRANCE}

Summary

France was one of those European countries where the COVID-19 pandemic started at the very beginning of 2020. It was here that the first COVID-19 patient in Europe was identified. The article describes the subjective calendar of events related to the course of the pandemic in this country. I present some selected phenomena and stages of the COVID-19 pandemic in France that may be important for assessing how was the quality of the fight against this scourge in this country. The history will make the final opinion.

Key words: coronavirus, COVID-19, France, hydroxychloroquine, pandemic, SARS-CoV-2 